Tersedia online di: http://ejournal-balitbang.kkp.go.id/index.php/JP
e-mail:jurnalpari@gmail.com
JURNAL PARI
volume 5 Nomor 1 Juli 2019
p-ISSN: 2502-0730
e-ISSN : 2549-0133

\title{
RANCANGAN ARSITEKTUR PROSES BISNIS SISTEM INFORMASI BASIS DATA KELAUTAN MENGGUNAKAN KERANGKA KERJA TOGAF PADA PUSAT RISET KELAUTAN
}

\author{
Eva Mustikasari \\ Pusat Riset Kelautan, Badan Riset Dan Sumberdaya Manusia Kelautan dan Perikanan, Jl. Pasir Putih \\ Raya II, Jakarta, 14430, Indonesia \\ Diterima tanggal : 21 Mei 2019 Diterima setelah perbaikan : 26 Juni 2019 \\ disetujui terbit : 10 Juli 2019
}

\begin{abstract}
ABSTRAK
Perancangan arsitektur Sistem Informasi basis data kelautan ini merupakan salah satu upaya pemenuhan kebutuhan bisnis strategi organisasi dan memudahkan akses informasi bidang kelautan dan perikanan bagi masyarakat dan para pemangku kepentingan. Rancangan arsitektur ini menggunakan kerangka kerja The Open Group Architecture Framework (TOGAF). TOGAF merupakan metoda terinci dan serangkaian alat pendukung untuk mengembangkan suatu Arsitektur Informasi. Kerangka ini mempertimbangkan aset perusahaan atau lembaga dan berfokus pada berbagai aplikasi bisnis mission-critical dan memungkinkan perancangan Arsitektur Informasi yang costumized. Selain arsitektur bisnis, TOGAF juga merupakan serangkaian metoda dan alat untuk membangun variasi arsitektur, termasuk arsitektur data, aplikasi dan teknologi. Data diperoleh dengan melakukan pengukuran model tingkat kematangan sebagai acuan dalam melakukan identifikasi dan analisis terhadap kondisi saat ini dari sisi TI dan Organisasi. Hasil rancangan arsitektur menunjukkan bahwa proses bisnis SI basis data Pusriskel terdiri dari 3 unsur utama, antara lain yaitu: Kompenen organisasi, fungsi bisnis dan entitas data masingmasing fungsi bisnis. Proses bisnis SI basis data Pusriskel dirancang dengan pendekatan prinsip tujuh kriteria informasi diantaranya adalah efektivitas, efisiensi, kerahasiaan, integritas, ketersediaan,kepatuhan dan keandalan. Ke tujuh kriteria ini digunakan sebagai kontrol untuk memenuhi kebutuhan penyediaan dan pengelolaan data dan informasi kelautan dan perikanan yang memiliki kapabilitas integritas data yang baik.
\end{abstract}

Kata Kunci : Basis data kelautan; Fungsi Bisnis; entitas Data; TOGAF; Arsitektur Informasi.

\begin{abstract}
ABSRACT
This architectural design of Marine Database Information System is one of the essential efforts to address the needs of the Organization's strategy to easily access the maritime and fisheries information for communities and stakeholders. Here, the architectural design uses the framework of The Open Group Architecture Framework (TOGAF). TOGAF is a detailed method and a series of supporting tools for developing an Information Architecture. This framework considers the assets of a company or institution and focuses on a variety of mission-critical business applications that also enables customized Information Architecture design. In addition, TOGAF is also a series of methods and tools for building architectural variations including data, applications, and technology. The data is obtained by measuring the maturity level model for a reference in identifying and analyzing current conditions in terms of IT and Organization. The architectural designs show that the database of information system in Pusriskel consists of three main elements, including Organization Components, Business Functions, and Data Entities of Each Business Function. The database of Sl's business in Pusriskel is designed with a 7-information criteria principle approach including effectiveness, efficiency, confidentiality, integrity, availability, obedience, and reliability. These 7-information criteria are used as a control to address the needs for the data provision and management of marine and Fisheries information which has good data integrity capabilities.
\end{abstract}

Keywords: Marine Database; Business Function; Data Entities; TOGAF; Information Architecture.

Korespondensi penulis:

Jalan Pasir Putih II Ancol Timur, Jakarta Utara

email : eva.mustikasari@gmail.com 


\section{PENDAHULUAN}

Aksessibilitas data dan informasi merupakan aspek yang berhubungan dengan hak masyarakat dan juga instansi pemerintah. Permasalahan akses bersumber pada implementasi Teknologi Informasi (TI) yang masih jauh dari cukup untuk mencapai implementasi e-goverment. Hal ini dapat dilihat dari kesiapan implementasi TI yang tidak seimbang pada setiap unit kerja serta sumber daya manusia (SDM) TI yang belum memadai. Hal ini menyebabkan pengelolaan data menjadi tidak tersistematis, dimana data-data masih tersebar secara tidak terstruktur di berbagai unit kerja serta integrasi data dan informasi lintas unit kerja belum terbangun. Dalam rangka meningkatkan pelayanan data dan informasi secara cepat, tepat dan akurat kepada masyarakat serta untuk melaksanakan kebijakan dalam pengelolaan data dan informasi di bidang kelautan dan perikanan, maka pengelolaan data dan informasi Pusat Riset Kelautan (Pusriskel) sebagai salah satu penyedia data dan informasi penelitian kelautan dan perikanan perlu disempurnakan. Untuk itu perlu adanya suatu upaya dalam mewujudkan tatanan sistem informasi (SI) yang baik dalam mendukung integrasi data dan informasi lintas sektor atau unit kerja. Salah satu upaya yaitu dengan melakukan kajian tentang perancangan arsitektur proses bisnis SI basis data kelautan dilingkup Pusriskel. Target yang ingin dicapai dalam penelitian ini adalah agar hasil dari perancangan arsitektur ini mampu memenuhi kebutuhan bisnis strategi organisasi dan memudahkan akses informasi bidang kelautan dan perikanan bagi masyarakat dan para pemangku kepentingan. Pemilihan kerangka kerja dengan metoda yang terinsi dan mudah beradaptasi dengan organisasi institusi atau perusahaan bertujuan agar hasil perancangan arsitektur ini dapat menciptakan SI basis data yang lebih terstruktur dilingkup Pusriskel sebagai penyedia data. Komponen-komponen yang dikembangkan dalam kerangka kerja tersebut adalah komponen proses bisnis, data, aplikasi dan teknologi. Komponenkomponen kunci ini memberikan visi yang jelas tentang bagaimana SI akan mendukung seluruh komponen yang terlibat dalam organisasi serta memberikan gambaran spesifik untuk proses pengembangan arsitektur SI secara berkelanjutan. (Dube R,M et all., 2011)

\section{DASAR TEORI}

\section{Tinjauan Organisasi Teknologi Informasi}

Organisasi merupakan sebuah unit fungsi (sosial/ bisnis/pemerintahan) yang terstruktur secara sistematis dan dikelola untuk memenuhi kebutuhan dalam mencapai kebutuhan kolektif secara berkelanjutan. Sedangkan organisasi Teknologi Informasi (TI) merupakan struktur manajemen yang akan menentukan hubungan antara fungsi dan posisi/ level layanan utama TI dalam membagi peran, tanggung jawab dan kewenangan untuk melaksanakan layanan TI yang telah ditetapkan. Pemahaman dasar tentang organisasi menyatakan bahwa Organisasi sangat penting bagi firma/perusahaan/institusi. Tidak ada satupun struktur organisasi yang dianggap paling benar. Organisasi dipengaruhi oleh faktor: teknologi, politik, budaya, lingkungan, sejarah, industri dan kompetisi. Personil organisasi sangat terpengaruh oleh struktur organisasinya. Organisasi harus mampu beradaptasi dengan cepat terhadap perubahan pasar dan kompetisi.

Hard competency yang harus dimiliki oleh personil organisasi TI diantaranya : memahami proses bisnis secara komprehensif, mengetahui konsep dasar proses bisnis, menguasai proses bisnis serta mampu membantu menjalankan proses bisnis. Sedangkan Soft competency yang harus dimiliki oleh personil organisasi antara lain : memiliki semangat untuk berprestasi, mampu membangun hubungan kerja, profesional, mampu berfikir analitik, mampu bekerja dalam team work serta memiliki pemikiran konseptual.

\section{Proses Bisnis}

Suatu proses bisnis dibangun untuk mendefinisikan secara spesifik aktifitas-aktifitas yang ada didalamnya. Suatu proses bisnis yang baik didalamnya mencakup tugas dan wewenang yang terkait dengan struktur organisasinya. Artinya proses bisnis tersebut harus merupakan proses bisnis yang berorientasikan pada jumlah dan kualitas produk keluaran, minimal dalam menggunakan sumber daya dan dapat beradaptasi sesuai dengan kebutuhan bisnis organisasi. Kesuksesan suatu sistem organisasi bisnis tergantung pada analisis dan perancangan proses bisnis yang baik.

Definisi diatas dapat juga diartikan sebagai kumpulan dari aktifitas yang mendukung proses-proses organisasi dalam suatu organisasi yang saling terkait satu sama lain untuk menghasilkan suatu keluaran demi terwujudnya tujuan dan sasaran strategis dari organisasi tersebut. Intinya bahwa dalam suatu proses bisnis harus mengetahui struktur organisasinya. Organisasi dalam proses bisnis dipandang sebagai sistem. Di dalam organisasi terjadi konversi dari masukan menjadi keluaran dan di perlukan banyak proses yang saling berhubungan dari fungsi-fungsi struktural yang ada. Proses berjalan sampai menjadi keluaran dan akan di dapat data yang di hasilkan. 
Diharapkan data dapat diolah menjadi informasi dan dikembalikan ke setiap fungsi masing-masing dimana akan di gunakan untuk mengukur kinerja, kontrol dan untuk pendukung dari pengambilan keputusan. Hasil keluaran dari suatu proses terkadang dibutuhkan oleh proses-proses yang lain untuk menghasilkan keluaran yang berbeda. Secara keseluruhan proses-proses tersebut menghasilkan keluaran yang melayani pihak eksternal yaitu stakeholder, keluaran ini dinamakan sebagai produk atau jasa.

\section{Sistem Informasi Basis Data Kelautan}

Pengelolaan basis data yang baik perlu ditunjang oleh sistem informasi (SI) yang baik pula sehingga input, proses dan outputnya menjadi lebih terstruktur dan terarah. Suatu SI yang baik adalah SI yang dapat memenuhi beberapa keperluan para penggunanya secara cepat,tepat dan mudah. Informasi yang dibutuhkan pun harus memenuhi kriteria control tertentu, guna mencapai tujuan bisnis yang diharapkan. Kriteria control tersebut antara lain: efektifitas, efisiensi, kerahasiaan, intergritas, ketersdiaan, kepatuhan dan keandalan [kridanto].

Untuk mewujudkan tatanan SI yang baik dan terstruktur dalam menunjang basis data kelautan khususnya dilingkup Pusriskel maka perlu rancangan arsitektur SI data kelautan. Dalam perancanganya, arsitektur SI basis data kelautan ini melibatkan 3 undur utama. 3 unsur tersebut antara lain sumberdaya manusia (People), Proses dan teknologi.

Dilingkup Pusat Riset Kelautan (Pusriskel), basis data kelautan salah satunya diperlukan dalam pemodelan. Jenis basis data tersebut dapat berupa data set insitu dan data reanalisis dengan berbagai metode seperti data asimilasi, optimal interpolation, grid analisys dan lain-lain. Selain itu terdapat pula jenis basis data yang merupakan luaran hasil model prediksi. Umumnya basis data jenis ini banyak disediakan oleh institusi-institusi riset internasional. Basis data kelautan ini dibutuhkan untuk pemodelan sebagai masukan data model, syarat batas model dan juga parameterisasi data model. Proses verifikasi dan validasi luaran model juga sangat membutuhkan basis data kelautan ini. Berbagai parameter telah tersedia di dalam basis data ini. [http:// www.zonabmi.org/basisdata/kelautan.html]

\section{Model Tingkat Kematangan CoBiT V.4}

Dalam penelitian ini model kematangan COBIT V.4.1 digunakan sebagai acuan untuk melakukan identifikasi terhadap kondidi saat ini dari sisi TI dan organisasi. Identifikasi dilakukan pada 4 domain
COBIT diantaranya adalah sebagai berikut.

1. Perencanaan dan pengorganisasian (PO).

2. Implementasi layanan $\mathrm{TI}(\mathrm{Al})$.

3. Keberjalanan layanan TI (DS).

4. Monitoring dan Evaluasi (ME).

Selanjutnya dilakukan pengukuran model tingkat kematangan (maturity model) pada setiap proses $\mathrm{TI}$ menurut kerangka kerja COBIT V.4.1. Dalam kerangka COBIT V.4.1 tingkat kematangan didefinisikan dalam 6 kategori (dari 0 sampai 5) sebagai berikut.

0 : Proses menejemen TI tidak ada sama sekali.

1: Proses TI Bersifat adhoc dan tidak terorganisasi.

2: Proses TI menikuti pola yang teratur.

3: Proses TI terdokumentasi dan dikomunikasikan.

4: Proses TI dimonitor dan di ukur.

5: Proses TI terbaik dan diotomatisasi,

Kebutuhan bisnis tercermin dengan adanya kebutuhan informasi. Informasi itu sendiri perlu memenuhi kriteria tertentu untuk mencapai tujuan bisnis. Tujuh kriteria kontrol untuk informasi sebagaimana dikemukakan dalam COBIT V.4.1 adalah sebagai berikut.

1). Efektivitas ; terkait dengan informasi yang relevan dan berhubungan pada proses bisnis serta disampaikan juga secara tepat waktu, benar, konsisten dan mudah. 2). Efisiensi ; terkait dengan ketentuan informasi melalui penggunaan sumber daya secara optimal. 3). Kerahasiaan ; terkait dengan pengamanan terhadap informasi yang sensitif dari pihak yang tidak berhak. 4). Integritas ; terkait dengan keakuratan dan kelengkapan informasi serta validasinya sesuai dengan nilai dan harapan bisnis. 5). Ketersediaan ; terkait dengan ketersediaan informasi pada saat kapanpun diperlukan oleh proses bisnis. 6). Kepatuhan ; terkait dengan kepatuhan pada hukum, regulasi maupun perjanjian kontrak. 7). Keandalan ; terkait dengan penyediaan informasi yang tepat bagi manajemen untuk mendukung operasional suatu entitas dan menjalankan tanggungjawab tata kelolanya. Ketujuh kriteria informasi ini dijadikan sebagai prinsip dasar dalam perancangan Al pada Balitbang KP.

\section{The Open Group Architecture Framework (TOGAF).}

TOGAF merupakan metoda terinci dan serangkaian alat pendukung untuk mengembangkan suatu Arsitektur Informasi. Kerangka ini mempertimbangkan aset perusahaan atau lembaga dan berfokus pada berbagai aplikasi bisnis missioncritical dan memungkinkan perancangan Arsitektur Informasi yang costumized. Selain arsitektur bisnis, TOGAF diluncurkan pada tahun 2009 sejak saat itu 
menjadi standar de-facto global untuk enterprise Architecture dan diadopsi oleh lebih dari $80 \%$ perusahaan terkemuka di Dunia. TOGAF juga merupakan serangkaian metoda dan alat untuk membangun variasi arsitektur, termasuk arsitektur data, aplikasi dan teknologi. Kelebihan TOGAf antara lain: fleksibel dan bersifat open source, sistematis, fokus pada siklus implementasi dan proses, resource base menyediakan banyak material referensi, kaya akan area teknis arsitektur, karena melibatkan banyak pihak terutama banyak memberikan best practice atau kejadian riil di dunia nyata. Kekyrangan TOGAF antara lain: tidak ada template standar untuk seluruh domain (misal untuk membuat blok diagram). TOGAf memberikan metode yang tentang bagaimana membangun dan mengelola serta mengimplementasikan rancangan Arsitektur dan sistem informasi yag disebut dengan ADM (Architecture Development Methode).

\section{METODOLOGI}

Perancangan arsitektur proses bisnis SI Basis data Kelautan pada Pusriskel ini menggunakan kerangka kerja TOGAF. Data diperoleh dengan melakukan pengukuran model tingkat kematangan sebagai acuan dalam melakukan identifikasi dan analisis terhadap kondisi saat ini dari sisi TI dan Organisasi. Nilai kematangan untuk kondisi eksisting dan kondisi harapan dihitung menggunakan kerangka kerja CoBiT V4. Perancangan terdiri dari beberapa lapisan Arsitektur, diantaranya adalah: Arsitektur bisnis yang menjelaskan proses bisnis, organisasi dan Sumber Daya Manusia (SDM) untuk memenuhi visi dan misi; Arsitektur data yaitu menjelaskan bagaimana diperoleh, diolah dan diproses; Arsitektur aplikasi yaitu bagaimana aplikasi dirancang sehingga berinteraksi satu dengan lainnya.; Arsitektur Teknologi yaitu menjelaskan infrastruktur hardware dan software yang mendukung aplikasi untuk berjalan dan berkomunikasi.

\section{HASIL DAN PEMBAHASAN}

Hasil Assessment dan analisis terhadap kondisi eksisting dan kondiso harapan proses bisnis SI basis data, diperoleh nilai kematangan kondisi eksisting sebesar 0.53 dan kondisi harapan sebesar 2.4. perhitungan menghasilkan nilai GAP sebesar 1.87. angka ini menunjukkan bahwa pusriskel berada pada tingkat kematangan antara 1 dan 2, artimya proses bisnis yang telah ada bersifat adhoc dan tidak terorganisasi. Alur proses bisnis SI basis data belum menunjukkan pola yang teratur, untuk itu perlu dilakukan perancangan ulang. Selain mengetahui nilai kematangan langkah berikutnya adalah mengetahui alur data Pusriskel.

Alur data penelitian Pusriskel ditunjukkan pada Gambar 1.

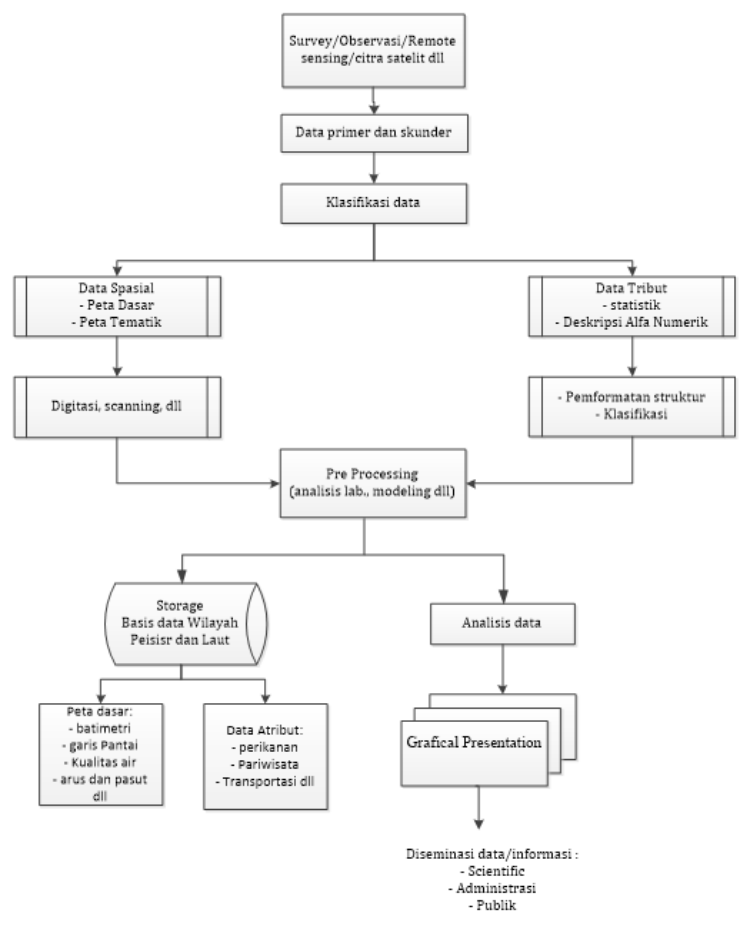

Gambar 1. Alur data Penelitian Pusriskel. 
Perancangana arsitektur proses bisnis SI basis data Pusriskel terdiri dari 3 unsur utama, antara lain yaitu 1). Kompenen Organisasi, 2). Fungsi Bisnis, 3). Entitas data masing-masing fungsi bisnis. Masingmasing unsur utama dapat diuraikan sebagai berikut: 1). Komponen Organisasi: Komponen organisasi terdiri dari : a.unit organisasi, dalam hal ini Pusriskel sebagai unit kapabilitas bisnis dari Badan Riset Kelautan dan Perikanan. b. Aktor, yaitu orang, organisasi atau sistem yang berada diluar pertimbangan model arsitektur akan tetapi mereka berinteraksi dengan arsitektur tersebut. c. Peran/Role, yaitu aktor yang diasumsikan berperan untuk melaksanakan tugas.

Dalam SI, komponen organisasi terdiri dari elemen sumberdaya manusia dan organisasi dimana oengelolaan SI secara strategis dapat memberikan gambaran taktis bagi kebutuhan integrasi dan standarisasi model operasi organisasi. Sedangkan komponen proses merupakan pengumpulan, penyimpanan, penggunaan dan penyebaran informasi.

2). Fungsi Bisnis: Fungsi bisnis dibagi menjadi tiga unsur, pertama yaitu mencakup fungsi bisnis dalam organisasi diantaranya: riset sumberdaya laut dan kewilayahan, riset teknologi kelautan, riset mitigasi adaptasi dan konservasi, laboratorium data dan tata usaha. Unsur kedua adalah layanan bisnis, yaitu mendukung kemampuan bisnis melalui pendefinisian interface secara jelas dan dikelola oleh organisasi. Unsur ketiga adalah Pross bisnis itu sendiri, yang menggambarkan alur dari interaksi antara fungsi bisnis dan layanan binisnya. 3). Entitas Data masing-masing Fungsi Bisnis: Entitas data ini terdiri dari data-data utama dan data pendukung dari masing-masing bidang riset. Entitas data juga memuat tentang tugas pokok dan fungsi dari masing masung bidang riset.

Dasar perancangan arsitektur proses bisnis mengacu pada teori Ward\&Papper dan Minztberg model, yang mencakup beberapa tingkatan diantaranya adalah: Struktur puncak dengan tugas pokok dan fungsinya yaitu menjalankan misi dengtan efektif. Midle-line berfungsi untuk menghubungkan strategi puncak dengan operasi inti. Operasi Inti yaitu pekerja yang terkait langsung dengan proses bisnis. Teknostruktur bertugas melayani organisasi untuk membantu proses bisnis organisasi. Terakhir adalah dukungan seluruh staff dalam menjalankan proses bisnis tersebut. Batasan pada perancangan ini adalah berlandaskan pada tugas pokok dan fungsi yang mengacu pada peraturan perundang-undangan dilingkup Badan Riset Kelautan dan Perikanan. Arsitektur proses bisnis ini dirancang dengan pendekatan prinsip 7 kriteria informasi untuk memenuhi kebutuhan penyediaan dan pengelolaan data yang memilikin kapabilitas inegritas data. Ketujuh kriteria tersebut antara lain diuraikan sebagai berikut:

1).Efektivitas ; terkait dengan informasi yang relevan dan berhubungan pada proses bisnis serta disampaikan juga secara tepat waktu, benar, konsisten dan mudah. 2).Efisiensi ; terkait dengan ketentuan informasi melalui penggunaan sumber daya secara optimal. 3).Kerahasiaan ; terkait dengan pengamanan terhadap informasi yang sensitif dari pihak yang tidak berhak. 4).Integritas ; terkait dengan keakuratan dan kelengkapan informasi serta validasinya sesuai dengan nilai dan harapan bisnis. 5).Ketersediaan ; terkait dengan ketersediaan informasi pada saat kapanpun diperlukan oleh proses bisnis. 6). Kepatuhan ; terkait dengan kepatuhan pada hukum, regulasi maupun perjanjian kontrak. 7).Keandalan ; terkait dengan penyediaan informasi yang tepat bagi manajemen untuk mendukung operasional suatu entitas dan menjalankan tanggungjawab tata kelolanya.

Hasil rancangan arsitektur proses bisnis SI Pusriskel ditunjukkan pada Gambar 2.

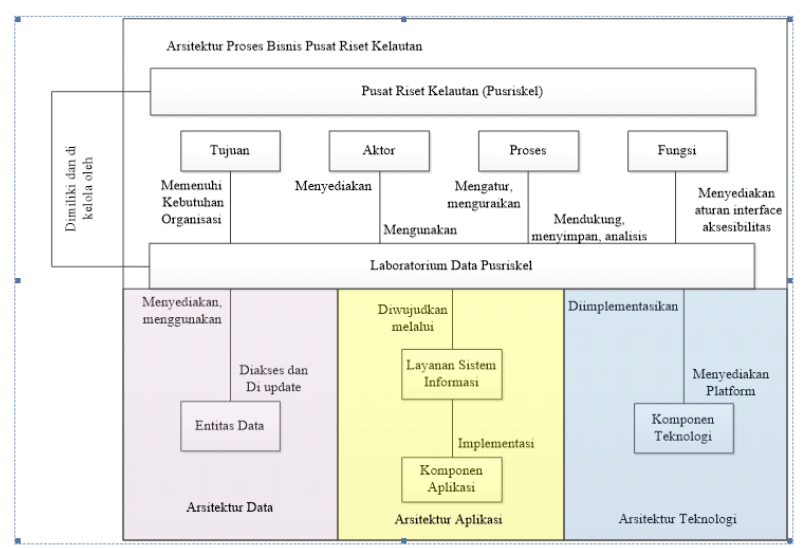

Gambar 2. Rancangan Arsitektur Proses Bisnis Pusriskel Menggunakan Kerangka Kerja TOGAF. 
Perancangan ini tidak dapat terlepas dari faktor kunci keberhasilan sebagai penentu sukses atau tidaknya sebuak proses bisnis. Faktor kunci keberhasilan internal dan ekternal Pusriskel antara lain sebagai berikut: 1). Mngembangkan organisasi dan tata kerja yang partisipatif, efisien dan efektif dengtan pemanfaatan Teknologi Informasi dan Komunikasi (TIK). 2). Meningkatkan pelayanan dasar berupa infrastruktur dan akses jaringan bagi seluruh unit kerja dan sumber daya manusia secara merata dan proporsional. 3). Mengembangkan dan menyediakan layanan akses informasi . 4). Pendorong percepatan pembangunan e-goverment.

\section{KESIMPULAN}

- Penggunaan kerangka kerja TOGAF dapat dugunakan untuk merancang arsitektur proses bisnis SI basis data pada Pusat Riset Kelautan (Pusriskel) dalam merumuskan perencanaan basis data yang strategis..

- Perancangan arsitektur Proses bisnis SI basis data kelautan merupakan strategi sebagai langkah awal inegrasi data untuk Pusriskel.

- Nilai kematangan mencapai 1.87, maka Pusriskel dianggap perlu melakukan implementasi perancangan terhadap proses bisnis SI basis data kelautan.

\section{DAFTAR PUSTAKA}

, Peraturan Kepala Badan Penelitian dan Pengembangan Kelautan dan Perikanan Nomor PER 15.1/Balitbang KP/2010, tentang Rencana StrategisBadan Penelitian dan Pengembangan Kelauta dan Perikanan Tahun 2010-2014,2010.

Keputusan Menteri No. Kep.26/

MEN/2011, tentang Unit kliring kementerian Kelautan dan Perikanan, 2011.

Nuryatno, R.Edi T., Fakhurroja, Hanif., Organisasi Teknologi Informasi, Materi Kuliah, Jurusan Chief Information Officer, InstitutTeknologi Bandung, 2010.

Dube R M., Dixir K Shantanu., Comprehensive Measurement Framework For Enterprise Architectures, International Journal Of Computer \& Information Technology (IJTSIT) Vol.3 No.4 August 2011.

Weske,M., Business Proces Management, Concept, Languages and Architecture, 2007.

Harmon,P., Business Process Change, A Guide for Business Managers and BPM and Six Sigma Professionals, 2thEdition, 2007.
COBIT Versi 4.1, IT, Governance Institute, 2007.

Surendro, K., Implementasi Tata Kelola Teknologi Informasi, juni, Penerbit Informatika, 2009.

Harris, PT., Enterprise Architecture and its roles in solving Business Issues. case of study of the NSW Departement of Lands. IEEE 8th International Conference on Computer and Information Technology Workshops, 2008

The Open Group Architecture Framework (TOGAF) Version 9. U.S: The Open Group, 2009.

Benson, Robert J.; Bugnitz, Thomas L: Walton,William B., From Business Strategy to IT Action. New jersey: John Wiley \& Sons, Inc, 2004.

Sessions, Roger, A Comparison of the Top Four Enterprises Architecture Methodologies. Object Watch, Inc., 2007.

Creswell, J.W., Research Design Qualitative, Quantitive, and Mixed Methode Approaches, Sage Publications, Second Edition, 2003

Ward J \& Peppard., Strategys Planning for Information System, Cranfield School of Management Cranfield, Bedfordshire, UK. 3th Edition, 2002.

Noprianto, Agung Y D, Wenando F A., Riview dan Studi Kasus EA TOGAF, www.academia.edu diunduh pada tanggal 18 Juni 2019 jam 11.13 wib. 